21. Спеціальна техніка : підруч. / за ред. I. С. Керницький. - Львів : Львів. держ. ун-т внутр. справ, 2010.- 354 с. ; Spetsialna tekhnika : pidruch. / za red. I. S. Kernytskyi. Lviv : Lviv. derzh. un-t vnutr. sprav, 2010.-354 s.

\title{
I.F. Kharaberiush \\ SPECIAL EQUIPMENT IN ADMINISTRATIVE ACTIVITIES OF LAW ENFORCEMENT BODIES
}

The article considers special equipment used in the administrative activities of law enforcement agencies, which is defined as organizational equipment. It is emphasized that the scientific and technical means, which we generally define as organizational equipment, play a significant role in the process of democratic formation of the state and effective administrative activity of law enforcement agencies. Factors emphasizing the need to use organizational equipment in the administrative activities of law enforcement agencies are presented. Organizational technology is seen as a means of law enforcement in general. The definition of the concept of "organizational technique" is given. The method of criterion selection is used to determine the scope of the concept of "organizational technique". According to the selected criteria the system-structural structure of organizational equipment of law enforcement agencies is investigated. To determine the system-structural structure of the organizational equipment of law enforcement agencies as a scientific category, the classical theory of organization was chosen. The basis for the system atization of organizational equipment is the hierarchical structure of law enforcement agencies engaged in administrative activities. It is proved that the defining requirement of the current legislation to the means of organizational equipment is the need for their certification and periodic verification.

Keywords: special equipment, administrative activity, organizational equipment, system, certification.

Стаття надійшла до редакції 23.04.2020 p.

УДК 342.7

\author{
М. Л. Шелухін, \\ О. А. Любчик
}

\section{ПРО КОНСТИТУЦЙНІСТЬ ЗАКОНУ, АБО ЧИ МОЖУТЬ УКРАЇНЦІ ЛІКУВАТИСЬ?}

У статті досліджуються законність прийняття та наслідки запровадження у дію Закону України «Про державні фінансові гарантії медичного обслуговування населення». На підставі аналізу норм міжнародного права, Конституції України та рімень Конституціийного Суду України обгрунтовується тезис про неконституційність цього закону та аналізуються негативні наслідки його запровадження в життя українського суспільства. Порівнюються поняття медичної допомоги та медичної послуги. Аналізуються негативні наслідки запровадження 
медичної реформи. Запропоновані шляхи вирішення проблеми прийняття законів які $є$ неконституиійними та протирічать діючому законодавству.

Ключові слова: конституйійність закону, легальність та легітимність закону, причини та наслідки прийняття неконституційного закону, медична реформа, «медична допомога» та «медична послуга», право людини на життя та здоров'я, правовий нігілізм.

\section{DOI 10.34079/2226-3047-2020-10-19-51-61}

Постановка проблеми. Останніми роками українське суспільство потерпає від багатьох кризових явищ, які проявляються в політичному житті, назріли в економічної сфері, загострились в соціальному забезпеченні та ініційовані в духовному житті громадян України. Всі ці негативні процеси обтяжуються військовими діями, які веде Україна, та епідеміологічною ситуацією. Постійні «реформи» та нововведення в правовому регулюванні звужують обсяг прав та свобод громадян, створюють штучні перепони на шляху їх реалізації та захисту. Запропонована «медична реформа», яка грунтується на Законі України № 2168-VIII від 19 жовтня 2017 року «Про державні фінансові гарантії медичного обслуговування населення» взагалі поставила під сумнів останнє і головне право кожної людини - право на здоров'я і саме життя. Проблема цього закону перш за все в його неконституційності, проте інші його негативні напрямки впливу на життя суспільства також будуть розглянуті в цьому досліджені.

Аналіз останніх досліджень і публікацій, в яких започатковано розв'язання даної проблеми. Проблеми реалізації права на життя та здоров'я в Україні вивчали такі фахівці в галузі права, як: С. В. Антонов, С. Б. Булеца, О. М. Берназ-Лукавецька, В. С. Віткова, В. Д. Волков, В. Г. Гінзбург, 3. А. Дікінова, Л. М. Дешко, О. А. Сникєєв, В. П. Заблоцький, 3. В. Каменєв, А. Б. Литовка, Г. А. Миронова, О. О. Прасов, І. Я. Смотров, І.Я. Сенюта, А. В. Тихомиров, І. В. Тимофєєв, М. К. Хобзей та ін. Проте проблема реалізації прав громадян України на здоров'я та саме життя поглиблюється та потребує подальшого вивчення.

Мета дослідження. Метою статті є 3'ясування законності прийняття та наслідків впровадження Закону України «Про державні фінансові гарантії медичного обслуговування населення», як правової основи медичної реформи в Украӥни.

Виклад основного матеріалу. Почати це дослідження було б доречно з цитування стаття 3 Конституції України, яка наголошує, що людина, її життя і здоров'я, честь i гідність, недоторканність і безпека визнаються в Україні найвищою соціальною цінністю. Також стаття додає: «Права і свободи людини та їх гарантії визначають зміст i спрямованість діяльності держави. Держава відповідає перед людиною за свою діяльність. Утвердження і забезпечення прав і свобод людини $є$ головним обов'язком держави» [1].

Одними з головних конституційних прав людини $є$ право на здоров'я та життя. Стаття 27 Конституції України прямо затверджує, що кожна людина має невід'ємне право на життя. Ніхто не може бути свавільно позбавлений життя. Обов'язок держави захищати життя людини. Кожен має право захищати своє життя і здоров'я, життя i здоров'я інших людей від протиправних посягань. Ще більш конкретно захищає права на здоров'я та життя стаття 49, яка закріплює право кожної людини на охорону здоров'я, медичну допомогу та медичне страхування. Охорона здоров'я забезпечується державним фінансуванням відповідних соціально-економічних, медико-санітарних і оздоровчо-профілактичних програм. Держава повинна створювати умови для ефективного й доступного для всіх громадян медичного обслуговування. У державних $i$ 
комунальних закладах охорони здоров'я медична допомога надається безоплатно, існуюча мережа таких закладів не може бути скорочена [1].

Суттєво доповнює цей перелік стаття 21 Конституції України, яка закріплює правило, згідно з яким права і свободи людини є невідчужуваними та непорушними. Стаття 22 визначає, що конституційні права і свободи гарантуються і не можуть бути скасовані та визнає, що зміст й обсяг прав і свобод при прийнятті нових законів або внесенні змін до чинних законів не може бути звужений.

Юридичне верховенство Основного Закону закріплює стаття 8, в якої закріплено що Конституція України має найвищу юридичну силу. Закони та інші нормативноправові акти приймаються на основі Конституції України і повинні відповідати їй [1]. Юридична доктрина також визнає ці положення обов'язковими правилами, за якими повинна діяти держава, однак аналіз нормативних актів, в тому числі і законів, які були прийняті в останні роки, свідчать про те що зараз на законодавчому рівні відбуваються суттєві утиски прав людини і громадянина в Україні.

Основні напрямки порушення конституційних прав людини на здоров'я та життя завдяки неузгодженості законодавства та прямого порушення в ньому норм Конституції наступні:

- скорочення державних та комунальних закладів охорони здоров'я, масова та системна зміна їх організаційно-правової форми що прямо протирічить ч.3 ст.49 Конституції України;

- з 2019 року Законом України «Про внесення змін до деяких законодавчих актів України щодо невідкладних заходів у сфері охорони здоров'я» та Законом України «Основи законодавства України про охорону здоров'я» (далі Основи) перекладено обов'язки держави щодо матеріально-технічного забезпечення та фінансового забезпечення комунальних закладів охорони здоров'я на органи місцевого самоврядування [2, розд. 1 , п.5; 3 , п.5, ст.14];

- 32019 року обмежена медична допомога громадянам в державних та комунальних медичних закладах завдяки введенням тарифів, лише в рамках яких держава гарантує безоплатну медичну допомогу [4, п.1, ч.1, ст.2];

- підміна понять «медична допомога» на невизначене в законодавстві та юридичнії доктрині «медична послуга», завдяки чому безоплатна «медична допомога» в державних та комунальних закладах охорони здоров'я стає «оплатною послугою» [3, п.4, ст.3; 4, п.1, ч.1 ст.2];

Щодо неконституційності використання в нормотворчості термина «медична послуга» замість «медична допомога» прямо вказує Конституційний суд України (далі КСУ) в своєму Рішенні від 25 листопада 1998 року N 15-рп/98 (справа про платні медичні послуги)[5]. Визнаваючи неконституційною Постанову КМУ від 25 листопада №1138 «Про затвердження переліку платних послуг, які надаються в державних закладах охорони здоров'я та вищих медичних закладах освіти» [6] це Рішення не називає дії, які перераховані в Переліку платних послуг, як послуги, а зазначає, що це $є$ «медична допомога».

Це Рішення також наголошує наступне: 1) визначає сутність та суттєві ознаки «медичної допомоги» (п. 2, абз. 8); 2) називає дії, які знаходяться в Переліку платних послуг, - «виконнання робіт» (п. 2, абз. 8); 3) визначає дії, які знаходяться в Переліку платних послуг і які відносяться до медичної допомоги, та дії, які за певних обставин можуть розглядатися як медична допомога (п. 2, абз. 7, 8); 4) визначає незначну частину положень із зазначеного Переліку, яка може розглядатися як послуги, надання яких безоплатно в державних закладах охорони здоров'я не може брати на себе держава (п. 2, абз. 9). 
Постанову КМУ від 25 листопада №1138 не відмінили повністю, але замість визнаних неконституційними видів «медичних послуг» додали нових, які протирічать не тільки вказаним рішенням КСУ але ж й існуючому легальному визначенню «медична допомога», яке надано в статті 3 Закону України «Основи законодавства України про охорону здоров'я» від 1992 року, а саме: «медична допомога - це діяльність професійно підготовлених медичних працівників, спрямована на профілактику, діагностику, лікування та реабілітацію у зв'язку з хворобами, травмами, отруєннями і патологічними станами, а також у зв'язку з вагітністю та пологами» [3].

Вказану правову позицію в Рішенні N 1-29/98 КСУ підтримав також у своєму Рішенні від 29 травня 2002 року N 10-рп/2002 щодо офіційного тлумачення положення ч. 3 статті 49 Конституції України: «...у державних і комунальних закладах охорони здоров'я медична допомога надається безоплатно» (справа про безоплатну медичну допомогу) [7].

У Рішенні КСУ N 10-рп/2002 було вирішено:

- положення ч. 3 статті 49 Конституції «у державних $i$ комунальних закладах охорони здоров'я медична допомога надається безоплатно» треба розуміти так, що в державних та комунальних закладах охорони здоров'я медична допомога надається всім громадянам незалежно від ї̈ обсягу та без попереднього, поточного або наступного їх розрахунку за надання такої допомоги;

- поняття «медична допомога», умови запровадження медичного страхування, у тому числі державного, формування і використання добровільних медичних фондів, а також порядок надання медичних послуг, які виходять за межі медичної допомоги, на платній основі в державних і комунальних закладах охорони здоров'я та перелік таких послуг мають бути визначені законом [7].

Правовою підставою «медичної реформи» в Україні став Закон України «Про державні фінансові гарантії медичного обслуговування населення» від 19 жовтня 2017 року (далі Закон) [4]. Як губка вбирає він негатив від суспільства, медичних працівників та наукового середовища, які доводять його неконституційність, суперечливість, неефективність та навіть аморальність.

Щодо неконституційності та невідповідності іншим діючим законам, треба звернути увагу, що про це прямо вказували Висновок Головного науково-експертного управління ВРУ від 07.06.2017 [8, П.1-11] та Зауваження Головного юридичного управління ВРУ 13.07.2017 [8, п.1-13] щодо законопроекту цього Закону. Але на ці числені та обгрунтовані доводи юристів уваги не звернули і Закон прийняли.

Які порушення Основного Закону допускає цей Закон, чому він був прийнятий всупереч Конституції України, рішенням КСУ та діючому законодавству, яка відповідальність може бути та яка повинна бути застосована в цьому та аналогічних випадках - ці питання потребують відповіді.

Досліджуючи вказані вище норми Конституції України, рішення КСУ та враховуючи аргументи юристів - практиків можна зробити висновки про те що Закон Украӥни «Про державні фінансові гарантії медичного обслуговування населення» та інші нормативно-правові акти, які були прийняті в зв'язку з ним протирічать Конститучії Украӥни та діючому законодавству в наступному:

1) Одним з головних порушень є використання невизначеного в законодавстві терміна «медична послуга» (яка є платною) та підміна їм терміна «медична допомога» (безоплатна) визначеного в ст.3 Основ, коли мова йде про діяльність 3 надання медичної допомоги в державних та комунальних закладах охорони здоров'я.

Відповідно Рішенню КСУ N 15-рп/98 «медична допомога» визначається низкою міжнародних договорів, таких як: Конвенція про мінімальні норми соціального 
забезпечення, ухваленої у Женеві 28 червня 1952 року (статті 1, 2), Свропейської Конвенції про соціальну та медичну допомогу, укладеної у Парижі 11 грудня 1953 року (статті 1, 8-17), Свропейського кодексу соціального забезпечення, прийнятого у Страсбурзі 16 квітня 1964 року (частина II), Конвенції про медичну допомогу та допомоги у разі хвороби, прийнятої у Женеві 25 червня 1969 року (пункти 1, 3), та одноіменної Рекомендації, ухваленої там же і того ж дня (статті 7-12, 34), Європейської соціальної хартії, підписаної у Страсбурзі 3 травня 1996 року (статті 1113), та інших міжнародних документів [5, абз.4, ч.4].

2) Введенням тарифів на так звані «медичні послуги» в рамках яких держава бере на себе зобов'язання та «гарантує» лікування громадянам, чим порушує ст.49 Конституції та протирічить Рішенню КСУ $\mathrm{N}$ 15-рп/98, який прямо вказував: «...неприйнятні пропозиції окремих державних органів щодо необхідності встановлення якихось меж безоплатної медичної допомоги у вигляді іï гарантованого рівня, надання такої допомоги лише неспроможним верствам населення чи «в рамках, визначених законом» тощо. Безоплатна медична допомога, передбачена Конституцією України і повинна надаватись усім громадянам у повному обсязі, тобто задовольняти потреби людини в збереженні або відновленні здоров'я» [5, п. 4, абз. 9].

3) Реалізація цього Закону має наслідком фактичне скорочення закладів охорони здоров'я державної та комунальної власності, що прямо протирічить Конституції України [1, ч. 4, ст.49]. Також скорочення таких закладів буде відбуватися завдяки тому що обов'язковою умовою укладання договорів 3 Національною службою здоров'я України (далі НСЗУ) $є$ автономізація закладу (перетворення в комунальне некомерційне/казенне підприємство) [10, абз.6].

На тому ж ресурсі вказано: «Національна служба здоров'я України буде закуповувати медичні послуги у закладів охорони здоров'я усіх рівнів надання медичної допомоги, організаційно-правової форми (крім бюджетної установи) та форми власності (далі - надавачів) і оплачувати їх за договором [10, абз.1].

Тобто з бюджетними (державними та комунальними) установами, які згідно ст.49 Конституції України повинні надавати безоплатну медичну допомогу направлену на: «...профілактику, діагностику, лікування та реабілітацію у зв'язку 3 хворобами, травмами, отруєннями і патологічними станами, а також у зв'язку з вагітністю та пологами» [3, ст.1] НСЗУ договори на фінансування їх діяльності згідно Закону не планують. Проте гроші передбачені в державному бюджеті на медицину будуть віддавати приватним та іншим «автономним» підприємствам та підприємцям.

Це остання крапка в діяльності щодо фактичного знищення державних та комунальних закладів охорони здоров'я та фактичне знищення безоплатної медицини в України, яку її громадяни сплачували і сплачують податками та іншими обов'язковими платежами.

4) Крім введення тарифів на «медичні послуги» та знищення системи медичних закладів охорони здоров'я цей Закон в статті 10 передбачає: «Основні засади оплати надання медичних послуг та лікарських засобів за програмою медичних гарантій». Кількість та формування тарифів які передбачає Закон дає підстави до висновку що навіть людина у якої є гроші не буде спроможна сама розрахувати кількість необхідних грошей для оплати за надані «послуги». Так вказано що тарифи можуть встановлюватися, зокрема, як:

1) глобальні ставки, що передбачають сплату надавачам медичних послуг фіксованої суми за визначену кількість послуг чи визначений період;

2) капітаційні ставки, які встановлюються у вигляді фіксованої суми за кожного пацієнта; 
3) ставки на пролікований випадок;

4) ставки на медичну послугу;

5) ставки за результатами виконання договорів про медичне обслуговування населення надавачем медичних послуг.

Зазначені ставки можуть використовуватися як разом, так і окремо одна від одної $[4$, ч.2, ст.10].

Більш детально про тарифи визначає Постанова КМУ від 5 лютого 2020 р. № 65 «Деякі питання реалізації програми державних гарантій медичного обслуговування населення у 2020 році» [11]. Ця Постанова затверджує Порядок реалізації програми державних гарантій медичного обслуговування населення у 2020 році. У цьому Порядку визначені механізми визначення тарифів, які без неаби якого знання математики споживач «медичної послуги» не здатний розрохувати і тому має довіряти розрахункам надавача послуг. В цьому присутній додатковий високий корупційний ризик, як з боку надавачів послуг, так і посадових осіб НСЗУ.

5) Прихильники запровадження «медичної реформи» наголошують що запроваджується право пацієнта на вибір лікаря. Але ж чи так це насправді?

У п. 3 ч. 1 ст. 6 Закону закріплено право пацієнта на вибір лікаря у порядку, встановленому законодавством. Стаття 9 Закону закріплює що в разі потреби у медичних послугах та лікарських засобах за програмою медичних гарантій пацієнт чи його законний представник реалізує своє право на вибір лікаря шляхом подання надавачу медичних послуг декларачії про вибір лікаря, який надає первинну медичну допомогу[4, ч.1, ст.9].

Надання медичних послуг і лікарських засобів за програмою медичних гарантій, пов'язаних з вторинною, третинною, паліативною медичною допомогою та медичною реабілітацією, здійснюється за направленням лікаря, який надає первинну медичну допомогу, або лікуючого лікаря у порядку, передбаченому законодавством, окрім випадків, коли згідно із законодавством направлення лікаря не вимагається [4, ч.5, ст.9].

І.Я. Сенюта наголошує що реалізація права на вільний вибір лікаря сповнена численних нормативних дисонансів. Відповідно до п. "д" ч. 1 ст. 6; ч. 1 ст. 38 Закону України "Основи законодавства України про охорону здоров'я", ч.2 ст.284 Цивільного кодексу України пацієнт має право на вільний вибір лікаря, якщо останній може запропонувати свої послуги.

Відповідно до статті $35^{1}$ Основ закріплено загальний порядок вибору сімейного лікаря. На вторинному і третинному рівнях надання медичної допомоги не передбачено вільного вибору лікаря, адже вказано, що лікуючого лікаря 3 надання вторинної чи третинної медичної допомоги в закладі охорони здоров'я, що забезпечує надання такої допомоги, визначає керівник цього закладу або уповноважена ним на прийняття відповідних рішень особа (ст. ст. $35^{2}, 35^{3}$ Основ). Хоча не варто забувати про норму ч. 2 ст. 34 Основ, в якій гарантовано право пацієнта вимагати заміни лікаря [12].

У висновку дослідниця слушно стверджує що видається, можливість пацієнта регламентована в межах одного законодавчого акта - Основ, але спостерігається нормативне багатоманіття в підходах: з одного боку, пацієнт може обирати будь-якого лікаря, проте з іншого - вибір сповнений перепон етапності. Підсумовуючи, вона доходить висновку: 1) при наданні медичної допомоги за програмою медичних гарантій право пацієнта на вільний вибір лікаря обмежено вибором лікаря первинної ланки; 2) при наданні медичної допомоги поза межами програми вільний вибір повинен забезпечуватись на підставі ст. ст. 6 і 38 Основ. 
В цьому дослідженні ми торкнулися деяких негативних аспектів «медичної реформи», більш недоліків визначили вже згадані Висновок Головного науковоекспертного управління ВРУ від 07.06.2017 [7] та Зауваження Головного юридичного управління 13.07.2017 [8] щодо проекту цього Закону, на які тодішня влада не звернула увагу.

Досліджуючи сутність та особливості «медичної реформи» в Україні спадає думка чому не тільки нелегітимні, але і нелегальні нормативно-правові акти, в тому числі закони діють та завдають шкоди суспільству? Відкідаючи фактори моральності влади та фактори зовнішнього впливу, спробуємо визначити недоліки правового механізму, які сприяють цьому. Відповідь очевидна - безвідповідальність влади в цілому та окремих іiі органів та посадових осіб зокрема. 3 метою недопущення прийняття нормативних актів, які порушують Конституцію України та протирічать рішенням КСУ пропонується закріпити в Законі України «Про регламент Верховної Ради України» наступні положення:

- у разі надання висновку Головного науково-експертного управління ВРУ або зауважень Головного юридичного управління ВРУ 3 приводу неконституційності поданого законопроекту, подальший його розгляд здійснюється після виправлення таких недоліків, або після розгляду законопроекту Конституційним Судом України;

- у разі надання висновку або зауважень 3 приводу того, що законопроект не відповідає діючому законодавству, подальший його розгляд здійснюється після виправлення таких недоліків;

- законопроект повинен подаватися до Головного науково-експертного управління ВРУ та Головного юридичного управління ВРУ завчасно, не пізніше ніж за 15 днів до його розгляду ВРУ.

Такі пропозиції грунтуються на тому що механізм законотворчості повинен мати запобіжники щодо порушень єдності, системності та несуперечності діючого законодавства. Наступними кроками щодо запобігання порушення Конституції України при прийнятті законів України має бути персональна юридична (не тільки політична) відповідальність посадових осіб, які мають право підпису закону, але не за те що поставили підпис під законом, який згодом визнали неконституційним, а за порушення Регламенту в частині щцодо вказаних висновків та зауважень.

Сьогодні у нової влади $є$ можливість зробити доленосний крок на зустріч народу України та відмінити другий етап «медичної реформи» в України, врятувати мільйони життів громадян та захистити їх право на здоров’я та саме життя. В умовах пандемії цей крок ще більш важливий та вкрай необхідний. Навіть до розповсюдження COVID 19 в Україні були великі проблеми з системою охорони здоров'я, наслідки іiі функціонування вражають.

Так виступ голови Комітету ВРУ з питань охорони здоров'я Ольги Богомолець на засіданні круглого столу, який відбувся 10 червня 2019 року, з теми: «Перемогти смерть: ключові чинники, що впливають на тривалість життя українців» свідчить про важкий стан із здоров’ям українців [13]. У своїй доповіді вона зазначає, що Україна належить до трійки європейських держав 3 найвищою інтенсивністю природного скорочення населення. За інформацією Державної служби статистики, у 2018 році померло 587,7 тисяч осіб, відповідно, за рік за рахунок природного скорочення (тобто різниці між числом народжених і померлих) населення зменшилось на 251,8 тисяч осіб. У січні - березні 2019 року народилося 76 125, а померло - 159264 осіб, отже, природний приріст становив - мінус 83139 особи. Основною причиною смерті протягом останніх років є серцево-судинні захворювання $(67,0 \%)$, на другому місці новоутворення $(13,6$ \%). Зовнішні причини призвели до 5,4 \% смертей. Наприклад, у 
Франції і Японії серцево-судинні захворювання стають причиною летальності в $29 \%$ випадків, а в США - $31 \%$.

Щорічно від онкологічних хвороб помирає понад 400 тисяч українців (у середньому щодня гине більше 1 тисячі осіб). Сьогодні в Україні налічується близько 1 мільйона хворих на злоякісні новоутворення, з них - близько 6 тисяч дітей. Причому показники онкозахворюваності мають стійку тенденцію до зростання, і наша держава посідає друге місце в Свропі за темпами поширення раку. Щорічно в Україні більше 150 тисяч осіб дізнаються, що вони онкохворі. Щодня рак виявляють у 450 людей.

Висновок. Проведене дослідження свідчить про неконституційність, а як наслідок нелегальність Закону України «Про державні фінансові гарантії медичного обслуговування населення», нелегальною та нелегітимною є «медична реформа», яка їм започаткована та впроваджується. Причинами можливості існування такого правового нігілізму влади, яка його приймала, є: існування лише політичної відповідальності за свою діяльність, відсутність механізмів юридичної відповідальності, яка створюють умови для подальшого розповсюдження цього небезпечного соціального та правового явища. Для подальшого розвитку держави та підтримки європейського вектору розвитку в напрямку захисту прав людини, збереження права входити до лав правових та соціальних держав, з метою об'єднання суспільства навколо великих економічних та соціальних зрушень, до яких прагне суспільство, треба такі захисні правові механізми напрацювати та захистити права громадян на здоров'я та життя.

\section{Список використаної літератури}

1. Конституція України: прийнята на п'ятій сесії Верховної Ради України 28 червня 1996 року // Відомості Верховної Ради України. - 1996. - № 30. - Ст. 141. ; Konstytutsiia Ukrainy: pryiniata na piatii sesii Verkhovnoi Rady Ukrainy 28 chervnia 1996 roku // Vidomosti Verkhovnoi Rady Ukrainy. - 1996. - № 30. - St. 141.

2. Про внесення змін до деяких законодавчих актів України щодо невідкладних заходів у сфері охорони здоров’я : Закон України від 20 грудня 2019 року № 421-IX19 // Голос України. - 2020. - 15 січня ; Pro vnesennia zmin do deiakykh zakonodavchykh aktiv Ukrainy shchodo nevidkladnykh zakhodiv u sferi okhorony zdorovia : Zakon Ukrainy vid 20 hrudnia 2019 roku № 421-IX19 // Holos Ukrainy. - 2020. - 15 sichnia.

3. Основи законодавства України про охорону здоров'я [Електронний ресурс] : Закон України від 19.11.1992 року № 2801-XII // Режим доступу : https://zakon.rada.gov.ua/laws/show/280112/ed20150101/find?text=\%CC\%E5\%E4\%E8\%F7 $\% \mathrm{ED} \% \mathrm{E} 0+\% \mathrm{E} 4 \% \mathrm{EE} \% \mathrm{EF} \% \mathrm{EE} \% \mathrm{EC} \% \mathrm{EE} \% \mathrm{E} 3 \% \mathrm{E} 0$; Osnovy zakonodavstva Ukrainy pro okhoronu zdorovia [Elektronnyi resurs] : Zakon Ukrainy vid 19.11.1992 roku № 2801-XII // Rezhym dostupu : https://zakon.rada.gov.ua/laws/show/280112/ed20150101/find?text=\%CC\%E5\%E4\%E8\%F7\%ED\%E0+\%E4\%EE\%EF\%EE\%EC\%ЕE $\% \mathrm{E} 3 \% \mathrm{E} 0$

4. Про державні фінансові гарантії медичного обслуговування населення [Електронний ресурс] : Закон України від 19 жовтня 2017 року, № 2168-VIII. - Режим доступу : https://zakon.rada.gov.ua/laws/show/2168-19; Pro derzhavni finansovi harantii medychnoho obsluhovuvannia naselennia [Elektronnyi resurs] : Zakon Ukrainy vid 19 zhovtnia 2017 roku, № 2168-VIII. - Rezhym dostupu : https://zakon.rada.gov.ua/laws/show/2168-19

5. Рішення Конституційного Суду України у справі за конституційним поданням 66 народних депутатів України щодо відповідності Конституції України (конституційності) Постанови Кабінету Міністрів України «Про затвердження переліку платних послуг, які надаються в державних закладах охорони здоров'я та вищих 
медичних закладах освіти» (справа про платні медичні послуги) від 25 листопада 1998 року N 15-рп/98 [Електронний ресурс]. - Режим доступу : https://zakon.rada.gov.ua/laws/show/v015p710-98; Rishennia Konstytutsiinoho Sudu Ukrainy u spravi za konstytutsiinym podanniam 66 narodnykh deputativ Ukrainy shchodo vidpovidnosti Konstytutsii Ukrainy (konstytutsiinosti) Postanovy Kabinetu Ministriv Ukrainy «Pro zatverdzhennia pereliku platnykh posluh, yaki nadaiutsia $\mathrm{v}$ derzhavnykh zakladakh okhorony zdorovia ta vyshchykh medychnykh zakladakh osvity» (sprava pro platni medychni posluhy) vid 25 lystopada 1998 roku N 15-rp/98 [Elektronnyi resurs]. - Rezhym dostupu : https://zakon.rada.gov.ua/laws/show/v015p710-98

6. Про затвердження переліку платних послуг, які надаються в державних закладах охорони здоров'я та вищих медичних закладах освіти [Електронний ресурс] : Постанова Кабінету Міністрів України від 17 вересня 1996 р. N 1138. - Режим доступу : https://zakon.rada.gov.ua/laws/show/1138-96-\%D0\%BF/ed19960917 ; Pro zatverdzhennia pereliku platnykh posluh, yaki nadaiutsia $\mathrm{v}$ derzhavnykh zakladakh okhorony zdorovia ta vyshchykh medychnykh zakladakh osvity [Elektronnyi resurs] : Postanova Kabinetu Ministriv Ukrainy vid 17 veresnia 1996 r. N 1138. - Rezhym dostupu : https://zakon.rada.gov.ua/laws/show/1138-96-\%D0\%BF/ed19960917

7. Рішення Конституційного Суду України у справі за конституційним поданням 53 народних депутатів України щодо офіційного тлумачення положення частини третьої статті 49 Конституції України «у державних і комунальних закладах охорони здоров'я медична допомога надається безоплатно» (справа про безоплатну медичну допомогу) від 29 травня 2002 року N 10-рп/2002 [Електронний ресурс]. - Режим доступу : https://zakon.rada.gov.ua/laws/show/v010p710-02 ; Rishennia Konstytutsiinoho Sudu Ukrainy u spravi za konstytutsiinym podanniam 53 narodnykh deputativ Ukrainy shchodo ofitsiinoho tlumachennia polozhennia chastyny tretoi statti 49 Konstytutsii Ukrainy «u derzhavnykh i komunalnykh zakladakh okhorony zdorovia medychna dopomoha nadaietsia bezoplatno» (sprava pro bezoplatnu medychnu dopomohu) vid 29 travnia 2002 roku N 10-rp/2002 [Elektronnyi resurs]. - Rezhym dostupu : https://zakon.rada.gov.ua/laws/show/v010p710-02

8. Висновок Головного науково-експертного управління Верховної Ради України від 07.06.2017 року [Електронний ресурс] - Режим доступу : http://w1.c1.rada.gov.ua/pls/zweb2/webproc4_1?pf3511=61566 ; Vysnovok Holovnoho naukovo-ekspertnoho upravlinnia Verkhovnoi Rady Ukrainy vid 07.06.2017 roku $\begin{array}{llllll}\text { [Elektronnyi } & \text { resurs]. } & - & \text { Rezhym }\end{array}$ http://w1.c1.rada.gov.ua/pls/zweb2/webproc4_1?pf3511=61566

9. Проект Закону про державні фінансові гарантії надання медичних послуг та лікарських засобів. Зауваження Головного юридичного управління 13.07.2017 року [Електронний ресурс] // Верховна Рада України : Офіційний веб-портал. - Режим доступу : http://w1.c1.rada.gov.ua/pls/zweb2/webproc4_1?pf3511=61566 ; Proekt Zakonu pro derzhavni finansovi harantii nadannia medychnykh posluh ta likarskykh zasobiv. Zauvazhennia Holovnoho yurydychnoho upravlinnia 13.07.2017 roku [Elektronnyi resurs] // Verkhovna Rada Ukrainy : Ofitsiinyi veb-portal. - Rezhym dostupu : http://w1.c1.rada.gov.ua/pls/zweb2/webproc4_1?pf3511=61566

10. Вимоги ПМГ-2020 [Електронний ресурс] // Національна служба здоров'я України : Єдиний веб-портал органів виконавчої влади України. - Режим доступу : https://nszu.gov.ua/likar-2020 (дата звернення 03.03.2020р.). ; Vymohy PMH-2020 [Elektronnyi resurs] // Natsionalna sluzhba zdorovia Ukrainy : Yedynyi veb-portal orhaniv vykonavchoi vlady Ukrainy. - Rezhym dostupu : https://nszu.gov.ua/likar-2020 (data zvernennia 03.03.2020 r.) 
11. Деякі питання реалізації програми державних гарантій медичного обслуговування населення у 2020 році [Електронний ресурс] : Постанова Кабінету Міністрів України від 5 лютого 2020 р. № 65. - Режим доступу : https://zakon.rada.gov.ua/laws/show/65-2020-\%D0\%BF\#n298; Deiaki pytannia realizatsii prohramy derzhavnykh harantii medychnoho obsluhovuvannia naselennia u 2020 rotsi [Elektronnyi resurs] : Postanova Kabinetu Ministriv Ukrainy vid 5 liutoho 2020 r. № 65. Rezhym dostupu : https://zakon.rada.gov.ua/laws/show/65-2020-\%D0\%BF\#n298

12. Сенюта I. Медична реформа: To be or not to be? [Електронний ресурс] / І. Сенюта // Юрист\&Закон. - 2018. - № 9. - Режим доступу : https://uz.ligazakon.ua/ua/magazine_article/EA011320 ; Seniuta I. Medychna reforma: To be or not to be? [Elektronnyi resurs] / I. Seniuta // Yuryst\&Zakon. - 2018. - № 9. - Rezhym dostupu : https://uz.ligazakon.ua/ua/magazine_article/EA011320

13. «Перемогти смерть: ключові чинники, що впливають на тривалість життя українців» [Електронний ресурс] : Виступ голови Комітету з питань охорони здоров'я Ольгою Богомолець на засідання круглого столу який відбувся 10 червня 2019 року у Верховній Раді України. - Режим доступу : https: // https://www.rada.gov.ua/news/Novyny/172805.html?search=\%D0\%9F\%D0\%B5\%D 1\%80\%D0\%B5\%D0\%BC\%D0\%BE\%D0\%B3\%D1\%82\%D0\%B8\%20\%D1\%81\%D0\%BC\% D0\%B5\%D1\%80\%D1\%82\%D1\%8C:\%20\%D0\%BA\%D0\%BB\%D1\%8E\%D1\%87\%D0\%BE $\% \mathrm{D} 0 \% \mathrm{~B} 2 \% \mathrm{D} 1 \% 96 \% 20 \% \mathrm{D} 1 \% 87 \% \mathrm{D} 0 \% \mathrm{~B} 8 \% \mathrm{D} 0 \% \mathrm{BD} \% \mathrm{D} 0 \% \mathrm{BD} \% \mathrm{D} 0 \% \mathrm{~B} 8 \% \mathrm{D} 0 \% \mathrm{BA} \% \mathrm{D} 0 \%$ B8,\%20\%D1\%89\%D0\%BE\%20\%D0\%B2\%D0\%BF\%D0\%BB\%D0\%B8\%D0\%B2\%D0\%B0 $\% \mathrm{D} 1 \% 8 \mathrm{E} \% \mathrm{D} 1 \% 82 \% \mathrm{D} 1 \% 8 \mathrm{C} \% 20 \% \mathrm{D} 0 \% \mathrm{BD} \% \mathrm{D} 0 \% \mathrm{~B} 0 \% 20 \% \mathrm{D} 1 \% 82 \% \mathrm{D} 1 \% 80 \% \mathrm{D} 0 \% \mathrm{~B} 8 \% \mathrm{D}$ 0\%B2\%D0\%B0\%D0\%BB\%D1\%96\%D1\%81\%D1\%82\%D1\%8C\%20\%D0\%B6\%D0\%B8\% D1\%82\%D1\%82\%D1\%8F\%20\%D1\%83\%D0\%BA\%D1\%80\%D0\%B0\%D1\%97\%D0\%BD \%D1\%86\%D1\%96\%D0\%B2 ; «Peremohty smert: kliuchovi chynnyky, shcho vplyvaiut na tryvalist zhyttia ukraintsiv» [Elektronnyi resurs] : Vystup holovy Komitetu z pytan okhorony zdorovia Olhoiu Bohomolets na zasidannia kruhloho stolu yakyi vidbuvsia 10 chervnia 2019 roku u Verkhovnii Radi Ukrainy. - Rezhym dostupu : https: // https://www.rada.gov.ua/news/Novyny/172805.html?search=\%D0\%9F\%D0\%B5\%D1\%80 \%D0\%B5\%D0\%BC\%D0\%BE\%D0\%B3\%D1\%82\%D0\%B8\%20\%D1\%81\%D0\%BC\%D0\% B5\%D1\%80\%D1\%82\%D1\%8C:\%20\%D0\%BA\%D0\%BB\%D1\%8E\%D1\%87\%D0\%BE\%D0 $\% \mathrm{~B} 2 \% \mathrm{D} 1 \% 96 \% 20 \% \mathrm{D} 1 \% 87 \% \mathrm{D} 0 \% \mathrm{~B} 8 \% \mathrm{D} 0 \% \mathrm{BD} \% \mathrm{D} 0 \% \mathrm{BD} \% \mathrm{D} 0 \% \mathrm{~B} 8 \% \mathrm{D} 0 \% \mathrm{BA} \% \mathrm{D} 0 \% \mathrm{~B} 8, \%$ 20\%D1\%89\%D0\%BE\%20\%D0\%B2\%D0\%BF\%D0\%BB\%D0\%B8\%D0\%B2\%D0\%B0\%D1 $\% 8 \mathrm{E} \% \mathrm{D} 1 \% 82 \% \mathrm{D} 1 \% 8 \mathrm{C} \% 20 \% \mathrm{D} 0 \% \mathrm{BD} \% \mathrm{D} 0 \% \mathrm{~B} 0 \% 20 \% \mathrm{D} 1 \% 82 \% \mathrm{D} 1 \% 80 \% \mathrm{D} 0 \% \mathrm{~B} 8 \% \mathrm{D} 0 \% \mathrm{~B} 2$ \%D0\%B0\%D0\%BB\%D1\%96\%D1\%81\%D1\%82\%D1\%8C\%20\%D0\%B6\%D0\%B8\%D1\%8 2\%D1\%82\%D1\%8F\%20\%D1\%83\%D0\%BA\%D1\%80\%D0\%B0\%D1\%97\%D0\%BD\%D1\% $86 \% \mathrm{D} 1 \% 96 \% \mathrm{D} 0 \% \mathrm{~B} 2$

\section{N.Shelukhin \\ O. Lyubchik}

\section{ON THE CONSTITUTIONALITY OF THE LAW, OR WHAT CAN UKRAINIANS TREAT?}

The article investigates the lawfulness of the adoption and the consequences of the implementation of the Law of Ukraine "On State Financial Guarantees of Public Health Services". On the basis of the analysis of the norms of international law, the Constitution of Ukraine and the decisions of the Constitutional Court of Ukraine, the thesis about the unconstitutionality of this law is substantiated and the consequences of its implementation in 
the life of Ukrainian society are analyzed. The concepts of health care and medical services are compared. The negative consequences of the introduction of medical reform are analyzed. Proposed ways to solve the problem of passing laws that are unconstitutional and contradict the current legislation.

Specific legal mechanisms of implementation of which will contribute to ensuring the constitutionality and legality of legislative activity are proposed. The main directions of violation of the Constitution of Ukraine of the introduced "medical reform", which was initiated by the Law of Ukraine "On State Financial Guarantees of Medical Services to the Population", have been identified.

The thesis about the illegality and illegitimacy of this law is confirmed, justification of the unconstitutionality and contradiction of the provisions of this law is made by the decision of the Constitutional Court of Ukraine. The conclusion was made about the necessity of termination of this Law and other normative acts adopted on its basis.

Keywords: constitutionality of the law, legality and legitimacy of the law, grounds for adopting an unconstitutional law, consequences of the unconstitutionality of the law, human right to life and health, legal nihilism.

Стаття надійшла до редакції 24.04.2020 р.

УДК 352.071.3(477)

\section{Ю.В. Камардіна \\ Ю.В. Ковейно}

\section{ЗАХИСТ ПРАВ ОРГАНІВ МІСЦЕВОГО САМОВРЯДУВАННЯ В УКРАЇНІ: ТЕОРЕТИКО-ПРАВОВІ ЗАСАДИ}

У статті розглянуто теоретико-правові засади захисту прав органів місцевого самоврядування, що обумовлено публічно-правовим статусом органів місиевого самоврядування. При зверненні до теми захисту прав органів місиевого самоврядування, акцентовано увагу на необхідності вироблення чітких критеріїв розмежування категорій «гарантії», «забезпечення», «охорона» та «захист», що дозволить вирішити актуальне завдання підвищення ефективності здійснення органами місиевого самоврядування завдань, функиій та повноважень. Встановлено, щзо органи місчевого самоврядування відіграють важливу роль у житті кожного громадянина, у правовідносинах з мешканиями територіальної громади, тому повинні швидко і ефективно реалізовуватись у фактичних суспільних відносинах, оскільки на сьогоднішній день реалізація та захист прав місиевого самоврядування $\epsilon$ першочерговим завданням будь-якої демократичної держави. Доведено, щзо саме держава має створити необхіднии механізм захисту прав органів місиевого самоврядування, який матиме реальну силу для вирішення проблеми правопорушень на місцевому рівні.

Ключові слова: органи місиевого самоврядування, захист прав органів місиевого самоврядування, судовий захист.

DOI 10.34079/2226-3047-2020-10-19-61-67 